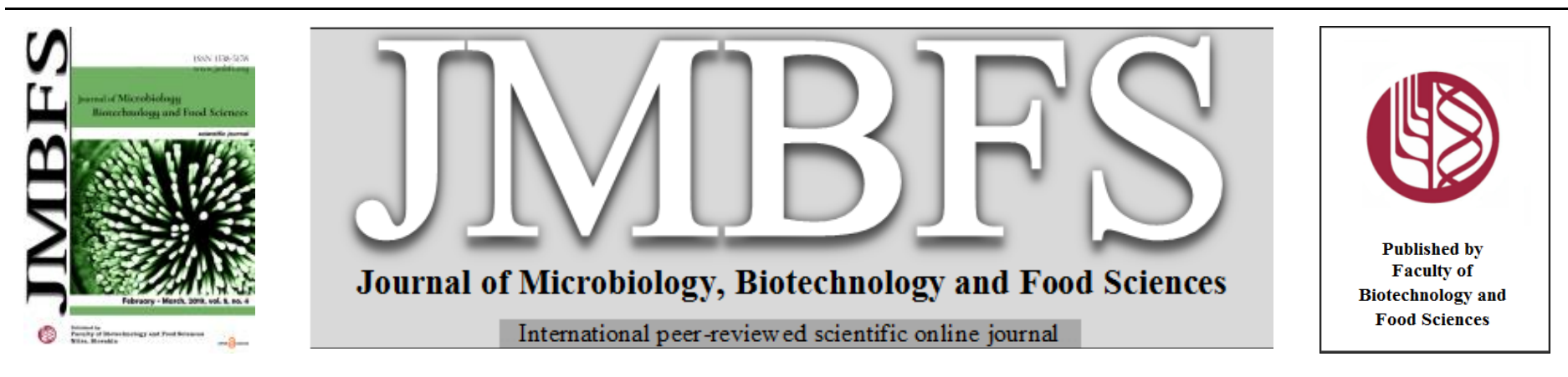

\title{
IDENTIFY THE NATURAL LEVELS OF MYCOTOXINS IN EGYPTIAN ROASTED PEANUTS AND THE DESTRUCTIVE EFFECT OF GAMMA RADIATION
}

\author{
Gomaa N. Abdel-Rahman, Yousef Y. Sultan, Salah H. Salem* and May M. Amer
}

$\operatorname{Address(es):~}$

National Research Centre, Department of Food Toxicology and Contaminants, 33 El-Bohouth St., P.O. Box: 12622,Dokki, Cairo, Egypt.

*Corresponding author: salah n82@yahoo.com

doi: 10.15414/jmbfs.2019.8.5.1174-1177

\section{ARTICLE INFO}

Received 16. 10. 2018

Revised 17. 12. 2018

Accepted 29. 12. 2018

Published 1. 4. 2019

Regular article

open $\mathcal{O}$ access

\begin{abstract}
A total of 36 roasted peanut samples were collected from 12 regions at 4 Egyptian governorates (Cairo, Giza, Alexandria and ElFaiyum) during 2017. Aflatoxins $\left(B_{1}, B_{2}, G_{1}\right.$ and $\left.G_{2}\right)$, ochratoxin $A$ and zearalenone were determined in the collected samples using HPLC. Seventy five percent of samples were contaminated with aflatoxins. Aflatoxin $B_{1}$ was the most dominant type, whereas aflatoxin $\mathrm{G}_{2}$ was found only in two samples at low levels. Samples were completely ochratoxin A and zearalenone-free. Quantitative results revealed that the samples of Al-Manshieh region at Alexandria governorate had the highest averages of aflatoxins $\mathrm{B}_{1}, \mathrm{~B}_{2}$ and $\mathrm{G}_{2}(33.15$, 3.66 and $0.22 \mu \mathrm{gkg}^{-1}$, respectively), while Al-Ajami samples at the same governorate had the highest average of aflatoxin $\mathrm{G}_{1}$ as 2.83 $\mu \mathrm{gkg}^{-1}$. Likewise, samples from Dokki at Giza governorate had high levels of total aflatoxins recording $26.33 \mu \mathrm{gkg}^{-1}$. Regarding to the effect of gamma radiation on aflatoxin $B_{1}$, the doses of 5, 10 and $20 \mathrm{kGy}$ were studied. The reduction levels of aflatoxin $B_{1}$ varied according to the spiking levels and dose of gamma radiation. The dose $5 \mathrm{KGy}$ was ineffective, whereas, a significant reduction in $\mathrm{AFB}_{1}$ was noticed using 10 and $20 \mathrm{KGy}$ recording $>26.7 \%$ reduction notably in samples spiked with $20 \mu \mathrm{gkg}^{-1} \mathrm{AFB}_{1}$ and treated with $20 \mathrm{KGy}$ (59\% reduction).
\end{abstract}

Keywords: Peanut, aflatoxins, radiation, ochratoxin A, zearalenone

\section{INTRODUCTION}

The peanuts are strategic crops in Egypt, where the cultivated area is 0.06 million hectares and the productivity is 0.21 million tons (3.2 tons/hectares) according to USDA (2018). Also, it considers one of the major exporting countries recording 57 million USD (Comtrade, 2017). Contamination of peanut by aflatoxin producing fungi is the major hazards during agriculture, harvesting, storage and marketing (El-Shanshoury et al., 2014). Therefore, the maximum levels <4 $\mu \mathrm{gkg}^{-1}$ total aflatoxins and $<2 \mu \mathrm{gkg}^{-1} \mathrm{AFB}_{1}$ in peanuts was established (European Commission, 2006). Aflatoxins are toxic secondary metabolites of Aspergillus flavus and Aspergillus parasiticus that contaminate human food especially peanut. They are known as mutagens, carcinogens, genotoxics and carcinogens that have healthy serious for animals and humans. Aflatoxin $\mathrm{B}_{1}$ is the most toxic one among aflatoxin types and is classified as carcinogenic compound group I (IARC 1993).

Abdel-Wahhab et al., (2011) reported that peanut is suitable substrates for aflatoxin production by Aspergillus members. They noticed that, the levels of aflatoxin $B_{1}$ and $B_{2}$ in peanut samples were 10.07 and $0.46 \mathrm{ngg}^{-1}$, respectively. Also, El-Gohary (1995) determined the aflatoxin levels in some foodstuffs collected from Alexandria. He reported that, about $7.5 \%$ of peanut samples were contaminated by aflatoxins. In another study, 14 out 60 of Egyptian peanuts samples $(23.3 \%)$ were contaminated with different mycotoxins such as aflatoxins, ochratoxins, sterigmatocystin and zearalenone(Youssef $\boldsymbol{e t}$ al., 2008) Although, Sultan and Magan (2010) found no ochratoxin A in tested peanut samples, they found that 5 of 12 Aspergillus section Circumdati isolates were ochratoxigenic referring to the potential contamination with ochratoxin A.

The radiation is an effective technique for preserving food against aflatoxins contamination. So, reduction of aflatoxins is important to ensure that contamination levels are kept or below the limits of national and international Public Health Authorities. In this respect, Kanapitsas et al., (2015) studied the effect of gamma radiation (10 kGy) on aflatoxin $\mathrm{B}_{1}$. They found that the aflatoxin $\mathrm{B}_{1}$ was reduced from 7.02 to $4.97 \mathrm{ngg}^{-1}$ recording $29 \%$ reduction. The efficiency of radiation process is depending on many factors such as radiation dose, moisture content, mycotoxin type, mycotoxin concentration and the presence of matrix components (Calado et al., 2014).
The present study was designed to estimate the update levels of mycotoxins i.e. aflatoxins $\left(B_{1}, B_{2}, G_{1}\right.$ and $\left.G_{2}\right)$, ochratoxin $A$ and zearalenone in roasted peanuts samples collected from Egyptian markets. Using gamma radiation in the reduction of the dominant contaminated mycotoxin was also investigated in this study.

\section{MATERIALS AND METHODS}

\section{Sampling}

In triplicates, roasted peanut samples ( $1 \mathrm{~kg}$ each) were collected from 12 regions at 4 Egyptian governorates during 2017: Cairo (Helwan, Al-Maadi, Al-Shuruq), Giza (Al-Omraniyah, Dokki, Atfih), Alexandria (Al-Manshieh, Abu-Qir, AlAjami) and El-Faiyum (Sinnures, Ibshway, Etsa).

\section{Effect of gamma radiation on aflatoxin $B_{1}$}

Control peanut sample, free aflatoxins, were grinded and spiked with $\mathrm{AFB}_{1}$ at three levels as low concentration $\left(2 \mu \mathrm{gkg}^{-1}\right)$, moderate concentration $\left(10 \mu \mathrm{gkg}^{-1}\right)$ and high concentration $\left(20 \mu \mathrm{gkg}^{-1}\right)$. The spiked samples were irradiated in transparent bags $(50 \mathrm{~g}$ each treatment) with gamma radiation at different doses $(0$, $5,10$ and $20 \mathrm{kGy})$ at room temperature $\left(25^{\circ} \mathrm{C}\right)$ in the National Center for Radiation Research and Technology (NCRRT), Cairo, Egypt. The irradiation was performed using a cobalt-60 $\gamma$-source irradiator with dose rate of $\sim 2.77$ $\mathrm{kGyh}^{-1}$. The irradiation were calibrated by the National Physical Laboratory using the dichromate dosimetry system (Aziz and Moussa, 2004; Alkhalifah et al. 2013). Aflatoxin $B_{1}$ was extracted and determined in the irradiated samples.

\section{Determination of aflatoxins}

The extraction and cleanup of aflatoxins $\left(\mathrm{AF}_{\mathrm{S}}\right)$ from collected and irradiated samples were performed according to $\mathrm{CB}$ method (AOAC, 2016 ). The final extracts were derivatized using $200 \mu 1$ hexane, $50 \mu 1$ trifluoroacetic acid (TFA) and then mixed well by vortex for $30 \mathrm{sec}$. The mixture was left to stand for 5 min. A mixture of $0.95 \mathrm{ml} \mathrm{H}_{2} \mathrm{O}: \mathrm{CH}_{3} \mathrm{CN}(9: 1 \mathrm{v} / \mathrm{v})$ was added and mixed well for $30 \mathrm{sec}$. After $10 \mathrm{~min}$, the upper layer was discarded preparing for HPLC analysis. 
Three replicates of peanut samples of each treatment were analyzed for AFs. The HPLC system used for determination was Ultimate 3000 Thermo Fisher system (Germany) equipped with auto sampler pump, fluorescence detector model: UV/Vies and a C18 column chromatography Phenomenex $(250 \times 4.6 \mathrm{~mm}, 5 \mu \mathrm{m})$ The mobile phase was methanol/water/acetonitrile (30:60:10, v/v/v) using an isocratic flow rate of $1 \mathrm{ml} \mathrm{min}^{-1}$ at $360 \mathrm{~nm}$ excitation and $440 \mathrm{~nm}$ emission wavelengths.

\section{Determination of ochratoxin A}

Ochratoxin A (OTA) was determined according to AOAC (2016 $)$. Fifty grams of grinded peanut was blended with $25 \mathrm{~mL} 0.1 \mathrm{M}$ phosphoric acid and $250 \mathrm{~m}$ chloroform for $3 \mathrm{~min}$ at medium speed. Ten gram of diatomaceous earth was added near end of blending. Mixture was filtered and $50 \mathrm{ml}$ was collected for cleanup. To the separatory funnel, $10 \mathrm{ml} 3 \%$ sodium bicarbonate was shaked gently with the $50 \mathrm{ml}$ portion. Five milliliter of the bicarbonate layer was passed throw conditioned $\mathrm{C} 18$ column (with $2 \mathrm{ml}$ methanol, $2 \mathrm{~mL}$ water, and $2 \mathrm{ml} \%$ sodium bicarbonate) followed with $2 \mathrm{ml} 0.1 \mathrm{M}$ phosphoric acid, then $2 \mathrm{mlH}_{2} \mathrm{O}$ OTA was eluted with $8 \mathrm{ml}$ ethyl acetate-methanol-acetic acid $(95+5+0.5)$ into $10 \mathrm{ml}$ test tube or vial containing $2 \mathrm{ml}$ water. The upper layer was collected and the remaining layer was rinsed twice with $1 \mathrm{ml}$ ethyl acetate and added to OTA extract. The extract was evaporated just to dryness on steam bath under $\mathrm{N}$. Samples were dissolved in mobile phase and analyzed with HPLC as mention in aflatoxin analysis using acetonitrile/water/acetic (99:99:2, v/v/v) isocratically at 1

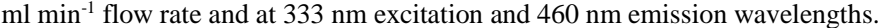

\section{Determination of zearalenone}

Five grams of ground peanut sample were placed in $50 \mathrm{ml}$ falcon tub and then 10 $\mathrm{ml}$ water was added. The tube was shaked and $10 \mathrm{ml}$ acetonitrile was added and the tube was reshaked.Then the mixture $\left(6 \mathrm{~g} \mathrm{MgSO}_{4}+1.5 \mathrm{~g} \mathrm{NaCl}\right)$ was added. The tube was shaked and centrifuged at $4000 \mathrm{rpm}$ for $5 \mathrm{~min}$. The supernatant was collected into $15 \mathrm{ml}$ tube containing $\left(1 \mathrm{~g} \mathrm{MgSO}_{4}+0.2 \mathrm{~g}\right.$ Primary Secondary Amine (PSA) and shaked for $1 \mathrm{~min}$ then centrifuged. For zearalenone (ZEA) determination, a volume of $4 \mathrm{ml}$ from the supernatant was evaporated using rotary evaporator then diluted with $2 \mathrm{ml}$ mobile phase and analyzed by HPLC. Same previous HPLC system was used. Samples were analyzed using acetonitrile: water $(50: 50 \mathrm{v} / \mathrm{v})$ at $274 \mathrm{~nm}$ excitation and $410 \mathrm{~nm}$ emission (Sebaei et al., 2012).

\section{Statistical analyses}

Data on the AFs contamination in collected peanut samples and effect of gamma radiation were analyzed using Statistic Version 10 (State Soft, Tulsa, OK, USA). The means of AFs concentrations were compared using analysis of variance (ANOVA, one way analyses) $(\mathrm{P}<0.05)$. Fisher's LSD method $(\alpha=0.05)$ was applied to compare differences between treatments.

\section{RESULTS AND DISCUSSION}

\section{Levels of mycotoxins in roasted peanuts}

The levels of roasted peanuts contamination with mycotoxins are illustrated in Table 1. All peanut samples collected from different Egyptian governorates were completely ochratoxin A and zearalenone-free. These results are disagreement with those noticed by Youssef $\boldsymbol{e t} \boldsymbol{a l}$. (2008) who revealed that the contamination ratio by ochratoxin $\mathrm{A}$ and zearalenone in peanut samples were $5 \%$ of each.
The presence of ochratoxin A and zearalenone in peanut samples return to dominant fungal genera associated with peanut from the farm to the roast process. Ochratoxin A is mainly produced by Aspergillus ochraceus, A carbonarius, A. niger and other species of Penicillium (Wagachaand Muthomi, 2008). While, zearalenone produced by Fusarium species such as $F$. oxysporum, F. sporotrichioides and F. sulphureum (Kumar et al., 2008). So, undetectable levels of ochratoxin A and zearalenone in the tested peanut samples may be return to absence of producer fungi for the two toxins.

Peanut is an important substrate for the growth and aflatoxin production by different species of Aspergillus. Regarding to the levels of aflatoxins in peanut samples (Table 1), Aflatoxin $B_{1}$ was the dominants type which found in $75 \%$ of samples followed by $\mathrm{AFB}_{2}(58 \%)$, then $\mathrm{AFG}_{1}(50 \%)$. $\mathrm{AFG}_{2}$ was noticed just in 2 samples $(17 \%)$. In general, Cairo governorate showed the lowest contamination with AFs, whereas Alexandria had the highest contaminated peanut samples recording $38.93 \mu \mathrm{gkg}^{-1}$ of total aflatoxins in $\mathrm{Al}$-Manshieh region. Increase of aflatoxins contamination in Alexandria samples may be return to the highly humidity in the north of Egypt. This hypothesis is in agreement with Embaby and Abdel-Galel (2014) who reported that the contamination fungi-produced aflatoxins in peanut samples of El-Behera governorate (north) were higher than peanut samples of Aswan governorate (south)

Results indicated also that $25 \%$ of peanut samples were exceeded the permissible limits of Egyptian standard (1990) as 5 and $10 \mu \mathrm{g} \mathrm{kg}^{-1}$ for $\mathrm{AFB}_{1}$ and total aflatoxin, respectively. Meanwhile, 42 and $33 \%$ of peanut samples were higher than maximum residual limits of $\mathrm{AFB}_{1}\left(2 \mu \mathrm{g} \mathrm{kg}^{-1}\right)$ and total aflatoxin $\left(4 \mu \mathrm{g} \mathrm{kg}^{-1}\right)$, respectively according to the European Commission (2006).

These results are nearly with El-Shanshoury $\boldsymbol{e t}$ al. (2014) who determined the aflatoxins in Egyptian peanut (collected from central delta provinces) and reported that the ratios of positive samples were 100 and $37.5(\%)$ for $\mathrm{AFB}_{1}$ and $\mathrm{AFG}_{1}$, respectively. Also, these results coincide with those reported by Youssef et al. (2008) who reported that, the contamination ratios by aflatoxins $\left(\mathrm{B}_{1}, \mathrm{~B}_{2}, \mathrm{G}_{1}\right.$ and $\mathrm{G}_{2}$ ) in untreated and roasted peanut were 20 and $10(\%)$, respectively. Meanwhile, the contamination ratio by aflatoxins in other Egyptian peanut samples was $42.5 \%$ (El-Maghraby and El-Maraghy, 1987).

The levels of aflatoxins in this study are in accordance with Younis and Malik (2003) who recorded aflatoxins levels of Sudanese roasted peanut ranged between 4 and $12 \mu \mathrm{g} \mathrm{kg}^{-1}$. Meanwhile, the levels of aflatoxins in peanut samples of present study were less than those determined by El-Shanshoury et al. (2014) who reported that the levels of aflatoxins ranged from 210 to $600 \mu \mathrm{g} \mathrm{kg}^{-1}$ for $\mathrm{AFB}_{1}$ and from $250-400 \mu \mathrm{g} \mathrm{kg}^{-1}$ for $\mathrm{AFG}_{1}$.

The high content of moisture in peanut can increase the levels of AFs as 10 fold during 3-day (Hell et al., 2008). Also, the common drying method for peanuts is sun drying that considered one of the ways to contamination by AFs (Santini $\boldsymbol{e t}$ al., 2015). So, the variation in AFs concentrations of different samples may be returned to the moisture content of peanut samples or the contamination levels during the drying process. Also, the contamination extent of peanut samples by aflatoxins depends on the levels of A. flavus colonization in cultivated soil, moisture content and temperature of soil. Likewise, the contamination levels of peanut samples by aflatoxins may be increased during harvest stage, drying process and storage conditions.

As well as, the levels of AFs in roasted peanuts depend on efficiency of roasting process. In this respect, Yazdanpanah et al. (2005) reported that the roasting process $\left(150^{\circ} \mathrm{C}\right.$ for 30 minutes) of contaminated peanuts can reduce the AFs levels. Also, Ozkarsli (2003) noticed that, the AFs levels of peanut was reduced by $48 \%$ after addition sodium chloride $\left(50 \mathrm{~g} \mathrm{~kg}^{-1}\right)$ during the roasting process

Table 1Concentrations of aflatoxins $\left(\mu \mathrm{gkg}^{-1}\right)$ in peanut samples collected from different Egyptian governorates

\begin{tabular}{|c|c|c|c|c|c|c|}
\hline \multirow{2}{*}{ Governorate } & \multirow{2}{*}{ City } & \multicolumn{5}{|c|}{ Concentration of aflatoxins $\left(\mu \mathrm{gkg}^{-1}\right)$} \\
\hline & & $\mathbf{B}_{1}$ & $\mathbf{B}_{2}$ & $\mathbf{G}_{1}$ & $\mathbf{G}_{\mathbf{2}}$ & Total \\
\hline \multirow{3}{*}{ Cairo } & Helwan & $1.83^{\mathrm{f}} \pm 0.08$ & $0.20^{\mathrm{e}} \pm 0.04$ & $0.35^{\mathrm{e}} \pm 0.05$ & ND & 2.38 \\
\hline & Al-Maadi & ND & ND & $\mathrm{ND}$ & ND & ND \\
\hline & Al-Shuruq & ND & ND & ND & ND & ND \\
\hline \multirow{3}{*}{ Giza } & Al-Omraniyah & $1.41^{\mathrm{f}} \pm 0.11$ & ND & ND & ND & 1.41 \\
\hline & Dokki & $22.55^{\mathrm{b}} \pm 0.17$ & $2.42^{b} \pm 0.06$ & $1.21^{\mathrm{c}} \pm 0.05$ & $0.15^{\mathrm{b}} \pm 0.02$ & 26.33 \\
\hline & Atfih & $3.47^{\mathrm{e}} \pm 0.07$ & $0.42^{\mathrm{d}} \pm 0.07$ & ND & ND & 3.89 \\
\hline \multirow{3}{*}{ Alexandria } & Al-Manshieh & $33.15^{a} \pm 0.41$ & $3.66^{\mathrm{a}} \pm 0.11$ & $1.90^{\mathrm{b}} \pm 0.05$ & $0.22^{a} \pm 0.03$ & 38.93 \\
\hline & Abu-Qir & $1.62^{\mathrm{f}} \pm 0.06$ & $0.23^{\mathrm{e}} \pm 0.07$ & $0.54^{\mathrm{d}} \pm 0.07$ & ND & 2.39 \\
\hline & Al-Ajami & $11.79^{c} \pm 0.17$ & $1.29^{\mathrm{c}} \pm 0.09$ & $2.83^{\mathrm{a}} \pm 0.06$ & ND & 15.91 \\
\hline \multirow{3}{*}{ El-Faiyum } & Sinnures & $0.70^{g} \pm 0.01$ & ND & ND & ND & 0.7 \\
\hline & Ibshway & $4.37^{\mathrm{d}} \pm 0.08$ & $0.54^{\mathrm{d}} \pm 0.05$ & $1.23^{c} \pm 0.09$ & ND & 6.14 \\
\hline & Etsa & $\mathrm{ND}$ & ND & $\mathrm{ND}$ & ND & ND \\
\hline LSD & & 0.43 & 0.16 & 0.13 & 0.03 & \\
\hline
\end{tabular}

Means followed by different subscripts within column are significantly different at the $5 \%$ level.

Effect of gamma radiation on aflatoxin $B_{1}$ reduction

Figs 1 and 2 show the effect of gamma radiation doses $(0,5,10$ and $20 \mathrm{kGy})$ on the reduction ratio of $\mathrm{AFB}_{1}$. Gamma radiation effect was studied only on $\mathrm{AFB}_{1}$ as prevalent form and the most potent of the other detected toxins i.e. $\mathrm{AFG}_{1}, \mathrm{AFB}_{2}$ and $\mathrm{AFG}_{2}$ (Kanapitsas et al., 2015). Control sample (aflatoxins-free) were spiked with $\mathrm{AFB}_{1}$ at three levels: low concentration $\left(2 \mu \mathrm{gkg}^{-1}\right)$, moderate concentration $\left(10 \mu \mathrm{gkg}^{-1}\right)$ and high concentration $\left(20 \mu \mathrm{gkg}^{-1}\right)$. 
The dose $5 \mathrm{kGy}$ had the less effect on $\mathrm{AFB}_{1}$ reduction $(<7.8 \%)$. The higher doses, 10 and $20 \mathrm{kGy}$, significantly decreased $\mathrm{AFB}_{1}$ in peanut samples at all spiking levels (26.7-59.0\% reduction). The reduction ratios were increased by increasing the concentration of aflatoxin $B_{1}$ in spiked samples notably at the dose 20kGy. This finding is not in accordance with Hooshmand and Klopenstein, (1995) who found that the doses of gamma radiation up to $20 \mathrm{kGy}$ did not affect AFB concentration in wheat, corn and soybeans. Meanwhile, Aziz and Youssef (2002) reported that, the $\mathrm{AFB}_{1}$ in peanut, corn and wheat was destructed completely at $20 \mathrm{kGy}$ of gamma radiation.

The quantity of particular radiolysis products after irradiation process will increase with irradiation dose (Skovgaard, 2000). Also, Calado et al. (2018) reported that the low mycotoxin will certainly be more protected from radiation effects than the high mycotoxin. These results are in agreement with Kanapitsas et al. (2015) who reported that the reduction ratio of $\mathrm{AFB}_{1}$ in spiked raisins samples was $29 \%$ after irradiation with $10 \mathrm{kGy}$. Also, Jalili et al. (2012) noticed that the reduction ratios of $\mathrm{AFB}_{1}$ in black and white pepper were increased with increase the irradiation doses from 5 to $30 \mathrm{kGy}$.

There are no available studies mentioned the mechanism of aflatoxin degradation by gamma radiation. However that of ochratoxin A degradation was explained by Calado et al. (2018). They reported that, the moisture content is a major factor for ochratoxin A reduction by gamma radiation. The applied radiation dose $(8.6 \mathrm{kGy})$ was suitable to accomplish a $98 \%$ reduction of the ochratoxin A dissolved in water $\left(2.5 \mu \mathrm{mol} \mathrm{L}^{-1}\right)$. But in the dried form, the same radiation dose eliminated just $12 \%$ of the ochratoxin $\mathrm{A}$. They concluded that, the efficiency of gamma radiation was increased in the presence of water because water ionization (water radiolysis) which lead to creating the reactive species such as $\mathrm{H}_{2} \mathrm{O}_{2}, \mathrm{H}_{3} \mathrm{O}^{+}, \mathrm{H}^{*}, \mathrm{HO}^{\circ}, \mathrm{HO}_{2}{ }^{\circ}, \mathrm{OH}^{-}$and $\mathrm{H}_{2}$. These reactive species are reactive against double bonds (aromatic or heterocyclic rings) and they initiate the hydrolysis of ochratoxin A.

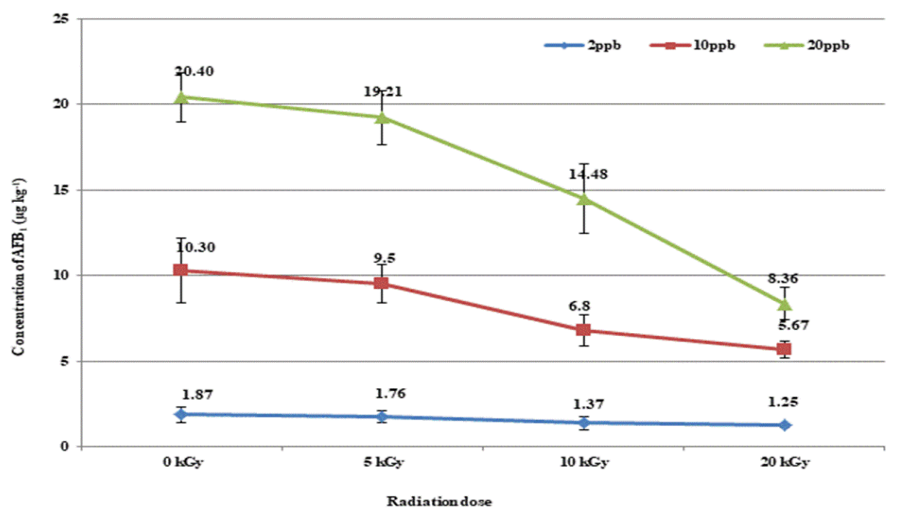

Figure 1 Effect of gamma radiation $(\mathrm{KGy})$ on $\mathrm{AFB}_{1}$ content in spiked peanut samples

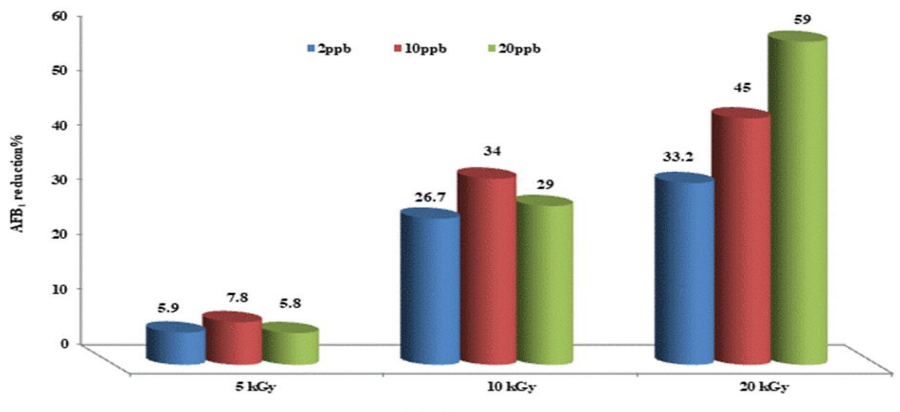

Figure 2 Reduction ratios of $\mathrm{AFB}_{1}$ in spiked peanut samples after gamma radiation.

\section{CONCLUSION}

Roasted peanut samples were ochratoxin A and zearalenone free and contained aflatoxins notably $\mathrm{AFB}_{1}$ in $75 \%$ of the samples. Samples from Alexandria regions were highly contaminated with aflatoxins. Gamma radiation was an effective technique to reduce that contamination. Around $60 \%$ of $\mathrm{AFB}_{1}$ content in spiked samples was reduced using $20 \mathrm{KGy}$ dose. This method is recommended to eliminate the $\mathrm{AFB}_{1}$ in contaminated peanut to the acceptable levels.

Acknowledgements: This study has been supported by the National Research Centre in Egypt via the research project No. 11040303 (2016 - 2019).

\section{REFERENCES}

ABDEL-WAHHAB, M. A., SEHAB, A. F., HASSANIEN, F. R., EL-NEMRSH, E., AMRA, H. A., ABDEL-ALIM, H. A. 2011. Efficacy of ozone to reduce fungal spoilage and aflatoxin contamination in peanuts. International Journal of Nuts and Related Sciences, 2(4), 1-14.

ALKHALIFAH, D. H. M., EL-SIDEEK, L., ELGAMMAL, M. H., ELSHERIF, M. H., ZAIED, S. A. F. 2013. Effect of gamma irradiation on microbiologica analysis, acrylamide content of coffee beans with special references to genotoxicity. Journal of Applied Sciences Research, 9 (4), 3157-3166.

AOAC.2016. Official methods of analysis. Natural toxins, 49.2.08, 20 $0^{\text {th }}$ edn., Chap. 49. Association of Official Analytical Chemists, Maryland, USA.

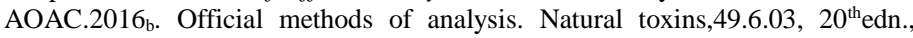
Chap. 49. Association of Official Analytical Chemists, Maryland, USA.

AZIZ, N. H., MOUSSA, L. A., FAR, F. M. 2004. Reduction of fungi and mycotoxins formation in seeds by gamma-radiation. Journal of Food Safety, 24(2), 109-127. https://doi.org/10.1111/j.1745-4565.2004.tb00379.x

AZIZ, N. H., YOUSSEF, B. M. 2002. Inactivation of naturally occurring of mycotoxins in some Egyptian foods and agricultural commodities by gamma irradiation. Egyptian Journal of Food Science (Egypt). J. Food Sci., 30, 167-177. CALADO, T., FERNÁNDEZ-CRUZ, M. L., VERDE, S. C., VENÂNCIO, A., ABRUNHOSA, L. 2018. Gamma irradiation effects on ochratoxin A: Degradation, cytotoxicity and application in food. Food Chemistry, 240, 463-471. http://dx.doi.org/10.1016/j.foodchem.2017.07.136

CALADO, T., VENÂNCIO, A., ABRUNHOSA, L. 2014. Irradiation for mold and mycotoxin control: A review. Comprehensive Reviews in Food Science and Food Safety, 13(5), 1049-1061. https://doi.org/10.1111/1541-4337.12095

COMTRADE, 2017. Major exporting countries of groundnuts. Available from: https://comtrade.un.org

EGYPTIAN STANDARD, 1990. Maximum limits for mycotoxin in food Egyptian Organization for standardization and quality control, part (1) aflatoxin. ES 1875-1990.

EL-GOHARY, A. H. 1995. Study on aflatoxins in some foodstuffs with special reference to public health hazard in Egypt. Asian-Australasian Journal of Animal Sciences, 8(6), 571-575. https://doi.org/10.5713/ajas.1995.571

EL-MAGHRABY, O. M. O., EL-MARAGHY, S. M. 1987. Mycoflora and mycotoxins of peanut (Arachishypogaea L.) seeds in Egypt.1-sugar fungi and natural occurrence of mycotoxins. Mycopathologia, 98(3), 165-170. https://doi.org/10.1007/bf00437651

EL-SHANSHOURY, A. R., EL-SABBAGH, S. M., EMARA, H. A., SABA, H. E. 2014. Occurrence of moulds, toxicogenic capability of Aspergillus flavus and levels of aflatoxins in maize, wheat, rice and peanut from markets in central delta provinces, Egypt. Int. J. Curr. Microbiol. App. Sci, 3(3), 852-865.

EMBABY, E. M., ABDEL-GALEL, M. M. 2014. Detection of fungi and aflatoxins contaminated peanut samples (Arachishypogaea L.). Journal of Agricultural Technology, 10(2), 423-437.

EUROPEAN COMMISSION, 2006. Final report of a mission carried out in China, in order to assess the facilities and measures in place for the control of aflatoxin contamination in peanuts intended for export into the EU. Report DG (SANCO)/8126/2006.

HELL, K., FANDOHAN, P., BANDYOPADHYAY, R., KIEWNICK, S. SIKORA, R., COTTY, P. J. 2008. Pre-and post-harvest management of aflatoxin in maize: An African perspective. Mycotoxins: Detection methods, management, public health and agricultural trade, 219-229. https://doi.org/10.1079/9781845930820.0219

HOOSHMAND, H., KLOPFENSTEIN, C. F. 1995. Effects of gamma irradiation on mycotoxin disappearance and amino acid contents of corn, wheat, and soybeans with different moisture contents. Plant Foods for Human Nutrition, 47(3), 227-238. https://doi.org/10.1007/bf01088331

IARC. 1993. Monograph on the evaluation of carcinogenic risk to human, Lyon France', International Agency for Research on Cancer, 56, 257-263

JALILI, M., JINAP, S. NORANIZAN, M. A. 2012. Aflatoxins and ochratoxin a reduction in black and white pepper by gamma radiation. Radiation Physics and Chemistry, $81(11)$,

1786-1788

http://dx.doi.org/10.1016/j.radphyschem.2012.06.001

KANAPITSAS, A., BATRINOU, A., ARAVANTINOS, A., MARKAKI, P. 2015. Effect of $\gamma$-radiation on the production of aflatoxin $B_{1}$ by Aspergillus parasiticus in raisins (Vitisvinifera L.).Radiation Physics and Chemistry, 106, 327-332. http://dx.doi.org/10.1016/j.radphyschem.2014.08.001

KUMAR, V., BASU, M. S., RAJENDRAN, T. P. 2008. Mycotoxin research and mycoflora in some commercially important agricultural commodities. Crop protection, 27(6), 891-905. https://doi.org/10.1016/j.cropro.2007.12.011

OZKARSLI, M. 2003. Effect of traditional-roasting and microwave-roasting on aflatoxin $B_{1}$ in peanuts. MSc Thesis, Cukurova University Institute of Natural and Applied Sciences, Adana, Turkey.

SANTINI, A., RAIOLA, A., MECA, G., RITIENI, A. (2015). Aflatoxins, ochratoxins, trichotecenes, patulin, fumonisins and beauvericin in finished products for human consumption. $J$ Clin. Toxicol., 5(4), 65-76 https://doi.org/10.4172/2161-0495.1000265 
SEBAEI, A. S., GOMAA, A. M., MOHAMED, G. G., EL-DIEN, F. N. (2012). Simple validated method for determination of deoxynivalenol and zearalenone in some cereals using high performance liquid chromatography. The American

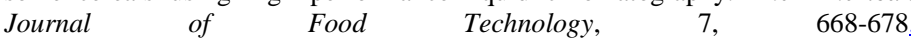
https://doi.org/10.3923/ajit.2012.668.678

SKOVGAARD, N. 2000. High-dose Irradiation: Wholesomeness of Food Irradiated with Doses above 10 kGy.-Report of a Joint FAO/IAEA/WHO Study Group. Technical report series, No. 890, 1999, vi+ 197 pages (available in English; French and Spanish in preparation). Paper back; WHO Marketing and Dissemination, 1211 Geneva 27, Switzerland; order no. 1100890. ISBN 924 120890 2; Sw. fr. 42.-/US \$37.80. In developing countries: Sw. fr. 29.20 International Journal of Food Microbiology, 1(58), 130-131..

SULTAN, Y., MAGAN, N. 2010. Mycotoxigenic fungi in peanuts from different geographic regions of Egypt. Mycotoxin Research, 26(2), 133-140 https://doi.org/10.1007/s12550-010-0048-5

USDA, 2018.World agricultural production. United States Department of Agriculture, Foreign Agricultural Service. Office of Global Analysis, Available from: https://apps.fas.usda.gov/psdonline/circulars/production.pdf

WAGACHA, J. M., MUTHOMI, J. W. 2008. Mycotoxin problem in Africa: current status, implications to food safety and health and possible management strategies. International journal of food microbiology, 124(1), 1-12. https://doi.org/10.1016/j.ijfoodmicro.2008.01.008

YAZDANPANAH, H., MOHAMMADI, T., ABOUHOSSAIN, G., CHERAGHALI, A. M. 2005. Effect of roasting on degradation of aflatoxins in contaminated pistachio nuts. Food and Chemical Toxicology, 43(7), 1135-1139. https://doi.org/10.1016/j.fet.2005.03.004

YOUNIS, Y. M., MALIK, K. M. 2003. TLC and HPLC assay of aflatoxin contamination in Sudanese peanuts and peanut products. Kuwait J. Sci. Eng., 30(1), 79-93.

YOUSSEF, M. S., EL-MAGHRABY, O. M. O., IBRAHIM, Y. M. 2008.

Mycobiota and mycotoxins of Egyptian peanut (Arachishypogeae L.) seeds. Int.

J. Bot., 4(4), 349-360. https://doi.org/10.3923/ijb.2008.349.360 